\title{
MARKET STRUCTURE AND THE PERSISTENCE OF SECTORAL REAL EXCHANGE RATES
}

\author{
YIN-WONG CHEUNG ${ }^{\mathrm{a}, 1}$, MENZIE CHINN ${ }^{\mathrm{a}, 2}$ and EIJI FUJII ${ }^{\mathrm{b}, *}$ \\ a Department of Economics, University of California, Santa Cruz, CA, USA \\ ${ }^{\mathrm{b}}$ Department of Economics, Otaru University of Commerce, Otaru, Japan
}

\begin{abstract}
We examine the relationship between market structure and the persistence of US dollar-based sectoral real exchange rates for 14 OECD countries. Our empirical results based on disaggregated data suggest that differences in market structure significantly determine the rates at which deviations from sectoral purchasing power parity decay. Specifically, industries with a larger price-cost margin are found to exhibit slower parity reversion of their sectoral real exchange rates. Further, as the degree of intra-industry trade activity increases, sectoral real exchange rate persistence becomes more pronounced. These findings suggest that an imperfectly competitive market structure contributes to the well-documented persistence in real exchange rates. Copyright (C) 2001 John Wiley \& Sons, Ltd.
\end{abstract}

KEY WORDS: imperfect competition; market structure; purchasing power parity

JEL CODE: F31; F40; L16

\section{INTRODUCTION}

The last few years have witnessed a remarkable transformation in the profession's views on the purchasing power parity (PPP). In contrast to the view prevailing in the 1980s, there now appears to be a consensus that long-run PPP holds. The recent evidence for real exchange rate stationarity comes from several sources. One set of studies appeals to long-spans of data, which encompass several exchange rate regimes. ${ }^{1}$ For post-Bretton Woods data, evidence regarding PPP is usually derived from panel-based unit root tests. By pooling observations across different countries, panel data unit root tests attain greater power to uncover PPP behavior (Wei and Parsley, 1995; Frankel and Rose, 1996; Oh, 1996; Wu, 1996; Engel et al., 1997). ${ }^{2}$

One intriguing empirical regularity is the extremely slow rate at which PPP deviations decay (Rogoff, 1996). Figure 1 displays the half-lives of PPP deviations reported in some recent studies. Most of these studies use the autoregressive (AR) coefficient as a sufficient statistic to characterize the time profile of the effects of a shock to PPP. The oft-cited 3.5-5.5 year half-life corresponds to the earlier panel studies (Wei and Parsley, 1995; Frankel and Rose, 1996). More recent panel studies (Wu, 1996; Papell, 1997) find somewhat more rapid reversion, with half-lives on the order of 2-2.5 years. Even these estimates appear to imply more sluggishness than one can attribute entirely to nominal rigidities alone.

Even though the recent studies provide some stronger evidence for real exchange rate convergence, the slow rate of parity reversion remains a puzzle (Rogoff, 1996). What factors account for such slow parity reversion? We believe that greater effort should be made to study the determinants of the rate of reversion. In examining the relationship between PPP and trade volume among G7 countries, Campa and Wolf (1997) find that greater geographical proximity and a larger market size accelerate the rate of PPP

\footnotetext{
* Correspondence to: Department of Economics, Otaru University of Commerce, Otaru, Hokkaido 047-8501, Japan. E-mail: efujii@res.otaru-uc.ac.jp

${ }^{1}$ E-mail: cheung@cats.ucsc.edu

${ }^{2}$ E-mail: chinn@cats.ucsc.edu
} 


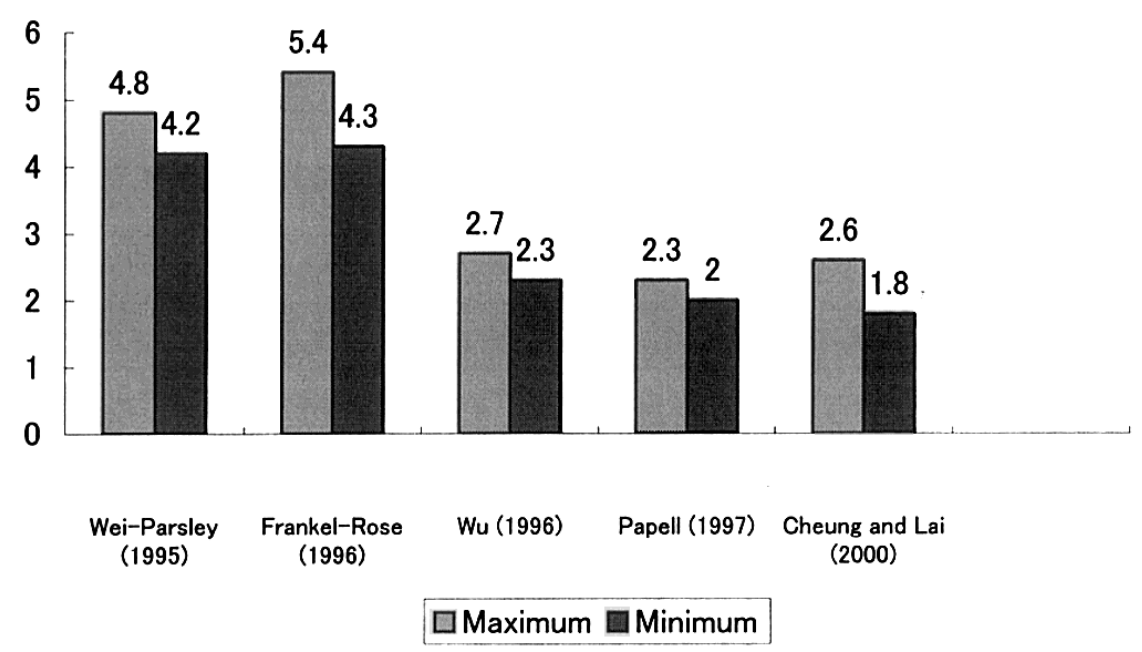

Figure 1. Half-lives of PPP deviations from various studies. The graph shows the maximum and minimum estimates of half-lives of PPP deviations in years from various studies.

reversion. Surprisingly, they find that a greater bilateral trade share leads to slower reversion, which seems to contradict the goods arbitrage-based view of long-run PPP. Adopting the macroeconomic perspective, Cheung and Lai (2000a) examine variables such as inflation, productivity growth, trade openness, and government expenditure to account for the differences in real exchange rate persistence across 94 countries. Although lower inflation and larger government spending are found to be associated with slower parity reversion, a substantial portion of the cross-country differences in the real exchange rate persistence remains unexplained.

One potential source of the real exchange rate persistence that is not considered in the preceding studies is the discriminatory pricing behavior of firms with market power, termed pricing to market (PTM) (Krugman, 1987). When markets are segmented, a monopolistically competitive firm's optimal pricing behavior can create a wedge between common currency prices of the same good destined to different markets, and consequently, violate the law of one price (LOP) which is a building block of PPP. There is substantial evidence of PTM (Knetter, 1993). ${ }^{3}$ The implications of PTM for PPP deviations can be quite significant. For instance, in examining the post-Bretton Woods real exchange rates between the US dollar and Canadian dollar, German mark, British pound, and Japanese yen, Feenstra and Kendall (1997) find that a substantial portion of the observed PPP deviation is attributable to the incomplete exchange rate pass-through due to PTM. Further, using a dynamic general equilibrium model, Faruqee (1995) shows that PTM behavior intensifies the degree of persistence in the real exchange rate under nominal rigidities. Similarly, a recent study by Bergin and Feenstra (1999) finds that PTM, along with staggered price contracts, can endogenously generate persistent real exchange rate dynamics in a general equilibrium setting. The findings of those studies suggest that discriminatory pricing behavior may explain at least in part the commonly observed excessive persistence in real exchange rates.

The theme of the current study is to empirically determine the market structure effects on real exchange rate persistence. Specifically, industry-level data are used to assess the effect of market imperfection on real exchange rate persistence. Since market structure determines PTM behavior, it is conceivable that industries and/or countries exhibiting different degrees of market imperfection display different adjustment speeds of PPP deviations. Thus, the use of national industry-level data enables us to study the effect of market structure on real exchange rate persistence. To our best knowledge, this is the first empirical study on the issue.

Using data on nine manufacturing industries from the US and 14 other OECD countries, we examine the relationship between market structure and the persistence of US dollar-based sectoral real exchange 
rates. Unlike most of the previous studies on PPP, the current study concentrates on sources of the real exchange rate persistence, rather than variability, from an industry market structure perspective. In analyzing the industry-level data, we also attempt to bridge the gap between studies using aggregated price series and ones with individual good price series (Ghosh and Wolf, 1994; Haskel and Wolf, 1999). Our empirical results, which have controlled for effects of macro variables, suggest that a greater degree of imperfectly competitive market structure is associated with a slower rate of sectoral PPP reversion. The finding implies that market imperfection, often considered as a source of violation of the LOP, contributes to the well-documented persistence in real exchange rates.

The remainder of this manuscript is organized as follows. Section 2 discusses the linkage between market structure and real exchange rate persistence. Section 3 describes the data, estimates the mean reversion coefficients of the sectoral real exchange rates, and constructs two proxies for market structure: the price-cost margin and the intra-industry trade index. In Section 4, we analyze the effects of market structure on the persistence of sectoral PPP deviations. Section 5 presents additional analyses based on alternative measures of market structure to check the robustness of the results obtained in Section 4. A summary is provided in Section 6.

\section{MARKET STRUCTURE AND REAL EXCHANGE RATE PERSISTENCE}

In an early paper relating market structure to PPP, Dornbusch (1987) examines the adjustment of relative prices to exchange rate movements. His analysis suggests that the response of relative prices critically depends on the following three factors: market integration or separation; substitution between domestic and foreign variants of a product; and market structure (or market organization in Dornbusch's nomenclature). When markets are segmented and the price elasticities of demand are not constant, a monopolistic firm's optimal pricing behavior in response to exchange rate changes leads to price discrimination by market destinations. ${ }^{4}$ Such pricing behavior was described as PTM by Krugman (1987). In a recent study, Feenstra and Kendall (1997) find PTM contributing substantially to the post-Bretton Woods PPP deviations among G5 countries. For instance, for the dollar/yen and dollar/sterling real rates, their estimates suggest that almost one third of the total PPP deviations are attributable to PTM.

Although the finding of Feenstra and Kendall (1997) suggests that market structure is important to PPP deviations, its implications for the persistence of PPP deviations are not clear. Faruqee (1995) provides some insight on the linkage between market structure and real exchange rate persistence. Specifically, utilizing a dynamic general equilibrium model under monopolistic competition and market segmentation, he shows that PTM intensifies the degree of real exchange rate persistence under nominal rigidities. ${ }^{5}$ In addition, the model offers a few more predictions on determinants of the real exchange rate persistence. Consider the real exchange rate dynamics implied by the model:

$$
q_{t}=\varphi q_{t-1}+\omega_{1}\left(m_{t}-m_{t}^{*}\right)+\omega_{2}\left(m_{t-1}-m_{t-1}^{*}\right)
$$

where

$$
\varphi=\frac{1-\sqrt{\Pi+2 \theta(1-\psi)}}{1+\sqrt{\Pi+2 \theta(1-\psi)}}, \quad \Pi=\frac{\gamma-1}{\varepsilon(\gamma-1)+1}, \quad \theta=1-\varepsilon \Pi
$$

and $q_{t}$ is the log of real exchange rate, $m_{t}\left(m_{t}^{*}\right)$ is the domestic (foreign) money supply, $\varepsilon>1$ is the constant elasticity of substitution between any two varieties from the same industry, $(\gamma-1)>0$ measures marginal disutility with respect to output, and $0.5<\psi<1$ is the expenditure share for home goods. ${ }^{6}$ A key implication of this model is that the $\mathrm{AR}$ coefficient $\varphi$ increases as the elasticity of substitution between varieties $(\varepsilon)$ rises. Noting that domestic and foreign goods are more substitutable, though only imperfectly, under intra-industry trade than inter industry-trade, Faruqee (1995) points out that a greater degree of intra-industry trade activity, ceteris paribus, leads to more persistent real exchange rate dynamics. The intuition is that as the elasticity of substitution rises monopolistically competitive exporting firms become more concerned with maintaining their prices in line with domestic competitors, leading to 
increased price rigidities in local currency terms. On the other hand, the real exchange rate persistence is reduced as the expenditure share on imported goods $(1-\psi)$ increases since it makes the domestic price level more susceptible to inflation induced by exchange rate depreciation, and hence, encourages more frequent price adjustment.

A link between market structure and real exchange rate persistence is also suggested by Bergin and Feenstra (1999). Using a general equilibrium framework, these authors show that PTM and staggered price contracts can endogenously create persistent real exchange rate dynamics. According to their results, the AR coefficient of the real exchange rate depends on two parameters: the cost share of labor input and the level of home market bias. The model also suggests that openness, reflected by a smaller home bias, would reduce the real exchange rate persistence.

The above studies highlight several industry-specific factors that may significantly determine the degree of real exchange rate persistence. These factors are the imperfectly competitive market structure, market segmentation, substitutability between domestic and foreign variants within an industry, and exposure to international trade. The objective of the current study is to empirically document the effects of these factors on real exchange rate persistence. In the subsequent sections, we first construct empirical measures of sectoral real exchange rate persistence and the industry market structure. Then we test if differences in market structure across industries are indeed systematically related to differences in sectoral real exchange rate persistence.

\section{DATA AND PRELIMINARY ANALYSIS}

\subsection{Data description}

Annual data on nine manufacturing sectors of the US and 14 other OECD countries are examined over period 1970-1993. The sectors (two-digit international standard industrial classification (ISIC) codes in parentheses) are: food (31); textiles, apparel, and leather (32); wood products and furniture (33); paper, paper products, and printing (34); chemical products (35); non-metallic mineral products (36); basic metal industries (37); fabricated metal industries (38); and other manufacturing (39). ${ }^{7}$ The country sample consists of Australia, Belgium, Canada, Denmark, Finland, France, Germany, Italy, Japan, the Netherlands, Norway, Portugal, Sweden, the UK, and the US. ${ }^{8}$ The industry and country coverage is determined by the availability of the data.

OECD Structural Analysis (STAN) Industrial Database and International Sectoral Database (ISDB) contain data on value added in current and 1985 constant prices, gross output, labor compensation, imports, exports, number engaged, and gross capital stock for each sector. ${ }^{9}$ Sectoral price deflator series are obtained by dividing the value added in current prices by that in constant prices. The data on bilateral nominal exchange rates vis-à-vis the US dollar are obtained from the IMF's International Financial Statistics (IFS).

\subsection{Estimating the rate of parity reversion: unit root tests and the mean reversion coefficient}

Using the nominal exchange rate series and sectoral price deflators, we define the dollar-based sectoral real exchange rate, in logarithm, as

$$
q_{i, t}^{j}=s_{t}^{j}+p_{i, t}^{j}-p_{i, t}^{\mathrm{US}}
$$

where $s_{t}^{j}$ is the log of the nominal exchange rate defined as the dollar price of country $j$ 's currency, $p_{i, t}^{j}$ and $p_{i, t}^{\mathrm{US}}$ are the $\operatorname{logs}$ of sector $i$ 's price indexes in country $j$ and of the US, respectively, and $t$ is the time subscript. With nine sectors and fourteen countries, a total of 126 dollar-based bilateral sectoral real exchange rates are constructed.

In order to estimate the speed of parity reversion, we first identify the series that revert to the parity using unit root tests. It is well known that standard unit root tests, such as the augmented Dickey-Fuller (ADF) tests, possess low power against the alternative of a stationary but persistent process. While there 
is no strictly uniformly most powerful invariant test for the unit root hypothesis, a modified ADF test called the ADF-GLS test developed by Elliott et al. (1996) is approximately uniformly most powerful invariant against the local alternatives. The superior performance of this test procedure is documented, for instance, by Pantula et al. (1994) and Stock (1994). We therefore test the sectoral real exchange rates for a unit root using the ADF-GLS test.

The ADF-GLS ${ }^{\tau}$ test which allows for a linear time trend is based on the following regression (for which the industry subscript and the country superscript are suppressed for brevity):

$$
(1-L) q_{t}^{\tau}=\alpha_{0} q_{t-1}^{\tau}+\sum_{k=1}^{p} \alpha_{k}(1-L) q_{t-k}^{\tau}+\varepsilon_{t}
$$

where $q_{t}^{\tau}$ is the locally detrended process under the local alternative of $\bar{\alpha}$ and is given by

$$
q_{t}^{\tau}=q_{t}-\tilde{\gamma}^{\prime} z_{t}
$$

with $z_{t}=(1, t)^{\prime} . \quad \tilde{\gamma}$ is the least squares regression coefficient of $\tilde{q}_{t}$ on $\tilde{z}_{t}$, where $\left(\tilde{q}_{1}, \tilde{q}_{2}, \ldots, \tilde{q}_{T}\right)=\left(q_{1},(1-\bar{\alpha} L) q_{2}, \ldots,(1-\bar{\alpha} L) q_{T}\right),\left(\tilde{z}_{1}, \tilde{z}_{2}, \ldots, \tilde{z}_{T}\right)=\left(z_{1},(1-\bar{\alpha} L) z_{2}, \ldots,(1-\bar{\alpha} L) z_{T}\right)$, and $L$ is the lag operator. The local alternative $\bar{\alpha}$ is defined by $\bar{\alpha}=1+\bar{c} / T$ for which $\bar{c}$ is set to -13.5 . The $\mathrm{ADF}-\mathrm{GLS}^{\mu}$ test, which does not allow for a linear time trend, involves the same procedure as the $\mathrm{ADF}-\mathrm{GLS}^{\tau}$ test, except that $q_{t}^{\tau}$ is replaced by the locally demeaned series $q_{t}^{\mu}$, which is obtained by setting $z_{t}=1$ and $\bar{c}$ to -7 . The ADF-GLS test statistic is given by the usual $t$-statistic for $a_{0}=0$ against the alternative of $a_{0}<0$. The lag parameter $p$ is determined in the following procedure. The maximum AR lag is set to 4 and the Akaike information criterion (AIC) is used to determine the first estimate of $p$. Then, the residuals from the selected model are checked for serial correlations. If there is no significant serial correlation in the estimated residuals, the number of lags determined by the AIC is used to conduct the test. Otherwise, the lag parameter will be increased by one until the resulting specification successfully removes serial correlation in the residuals.

Table 1 summarizes the unit root test results. According to ADF-GLS statistics, 31 of the 126 sectoral real exchange rates exhibit a significant deterministic time trend. Among these 31 series the ADF-GLS ${ }^{\tau}$ test rejects the unit root hypothesis in 17 cases. Of the 95 sectoral real exchange rates without a significant

\begin{tabular}{|c|c|c|c|c|c|c|c|}
\hline \multirow[t]{3}{*}{ ISIC code and classification description } & \multicolumn{2}{|c|}{ No trend } & \multicolumn{2}{|c|}{$\begin{array}{l}\text { Linear time } \\
\text { trend }\end{array}$} & \multicolumn{3}{|c|}{$I(0)$ series } \\
\hline & \multirow[t]{2}{*}{$I(0)$} & \multirow[t]{2}{*}{$I(1)$} & \multirow[t]{2}{*}{$I(0)$} & \multirow[t]{2}{*}{$I(1)$} & \multirow[t]{2}{*}{ Total } & \multicolumn{2}{|c|}{ Range of $\mathrm{MRC}_{i}^{j}$} \\
\hline & & & & & & Min. & Max. \\
\hline 31 Food & 4 & 7 & 3 & 0 & 7 & 0.053 & 0.722 \\
\hline 32 Textiles, apparel and leather & 4 & 4 & 4 & 2 & 8 & 0.205 & 0.778 \\
\hline 33 Wood products and furniture & 5 & 8 & 1 & 0 & 6 & 0.383 & 0.743 \\
\hline 34 Paper, paper products and printing & 8 & 3 & 0 & 3 & 8 & 0.283 & 0.723 \\
\hline 35 Chemical products & 8 & 5 & 0 & 1 & 8 & 0.560 & 0.733 \\
\hline 36 Non-metallic mineral products & 4 & 2 & 7 & 1 & 11 & 0.376 & 0.739 \\
\hline 37 Basic metal industries & 4 & 6 & 1 & 3 & 5 & 0.411 & 0.504 \\
\hline 38 Fabricated metal products & 9 & 4 & 1 & 0 & 10 & 0.343 & 0.811 \\
\hline 39 Other manufacturing & 5 & 5 & 0 & 4 & 5 & 0.575 & 0.752 \\
\hline Total & 51 & 44 & 17 & 14 & 68 & 0.053 & 0.811 \\
\hline
\end{tabular}

Table 1 . Summary of the unit root test results

Each entry, except in the last two columns, presents the number of the sectoral real exchange rate series in the corresponding category. The columns under the heading 'No trend' contain the results for the series without a significant deterministic trend at the $5 \%$ level. Similarly, the columns under 'Linear time trend' contain the results for the series which exhibit a significant deterministic trend. $I(0)$ and $I(1)$ indicate the orders of integration as determined by ADF-GLS tests. The $10 \%$ finite sample critical values from Cheung and Lai (1995) are used to evaluate significance of ADF-GLS test statistics. The last three columns contain the total number of $I(0)$ series in each industry and the corresponding range of the mean reversion coefficient (MRC $\left.{ }_{i}^{j}\right)$ defined by Equation (6). 
time trend, the unit root null hypothesis is rejected in 51 cases. The rejection rate ranges from $35 \%$ for the basic metal industries and the other manufacturing to $78 \%$ for the non-metallic mineral products.

As a measure of the parity reversion rate for the $I(0)$ sectoral real exchange rates, we define the mean reversion coefficient for industry $i$ of country $j$ as

$$
\mathrm{MRC}_{i}^{j} \equiv 1+\hat{\alpha}_{0}
$$

where $\hat{\alpha}_{0}$ is the implied AR(1) coefficient estimated from the ADF-GLS Equation (4). ${ }^{10}$ The closer $\mathrm{MRC}_{i}^{j}$ is to unity, the more persistent the sectoral real exchange rate is, thus, the slower the speed of parity reversion. ${ }^{11}$ The last two columns of Table 1 report the ranges of $\mathrm{MRC}_{i}^{j}$ of the $I(0)$ sectoral real exchange rate series. Among all $I(0)$ sectoral real exchange rates, the value of $\mathrm{MRC}_{i}^{j}$ ranges from 0.053 (food, Canada) to 0.811 (fabricated metal products, Italy) with the sample mean equal to $0.579 .{ }^{12}$ Note the wide range of the rates at which the sectoral real exchange rates revert to the parity condition. The variation within sectors (across countries) is also fairly substantial in many cases, and is most pronounced for the food industry with the range from 0.053 (Canada) to 0.722 (Belgium). The basic metal industry has the narrowest range of $\mathrm{MRC}_{i}^{j}$ values from 0.411 (UK) to 0.504 (Japan). In Section 4 we investigate the empirical relationships between the parity reversion rate, $\mathrm{MRC}_{i}^{j}$, and market structure.

\subsection{The price-cost margin}

Next we devise a proxy for market structure. Our first measure is the price-cost margin (PCM) which approximates the profitability of an industry. Define the PCM for industry $i$ of country $j$ in period $t$ as

$$
\mathrm{PCM}_{i, t}^{j}=\frac{V_{i, t}^{j}-M_{i, t}^{j}-W_{i, t}^{j}}{V_{i, t}^{j}}=\frac{V A_{i, t}^{j}-W_{i, t}^{j}}{V A_{i, t}^{j}+M_{i, t}^{j}}
$$

where $V_{i, t}^{j}$ is the value of total production, $M_{i, t}^{j}$ is the cost of materials, $W_{i, t}^{j}$ is labor compensation, $V A_{i, t}^{j}$ $\left(=V_{i, t}^{j}-M_{i, t}^{j}\right)$ is the value added of industry $i$ in country $j$ in period $t$. Since PCM can be directly observed from accounting data, it is widely utilized as a measure of market structure (Campa and Goldberg, 1995).

The STAN Industrial database contains data on gross output, value added, and labor compensation. The cost of materials is calculated by subtracting nominal value added from nominal gross output. The information on PCM data is summarized in Table 2. To save space we report only the mean and standard deviation of the calculated PCMs for each industry in each country over the sample period. The data indicate that there is much variation in PCMs across both industries and countries. For the 'other manufacturing' classification, the range of national mean PCMs is 1.83 , which is the largest among the industry groups under investigation. The ranges of mean PCMs of the remaining industry groups are all less than 0.23 . The variation of the mean PCMs within a country is most substantial for Belgium as indicated by the range of 1.316 . On the other hand, for Norway the range of the industry mean PCMs is 0.076 , the smallest among the 15 countries.

\subsection{The intra-industry trade index}

Another way to capture the market structure of an industry is to characterize the nature of competition via substitutability between domestic and foreign products. The idea of utility gain from product differentiation within an industry (Dixit and Stiglitz, 1977) provides a plausible explanation for the predominance of intra-industry trade (IIT) among developed countries, and is an essential ingredient of the modern approach to international trade (Helpman, 1981; Grossman and Helpman, 1991; Krugman, 1995). Where IIT takes place, domestic and foreign firms supply product varieties that are differentiated but still possess substitutability for one another. Under such circumstances, exporting firms will have some pricing power for their differentiated products. Also, due to the substitutability with domestic variants, exporters tend to be more concerned with stabilization of prices in local currency terms than under inter-industry trade. Consequently, Faruqee (1995) shows that sectors with a greater degree of intra-industry trade exhibit a greater degree of PTM, which in turn leads to more persistent real exchange 


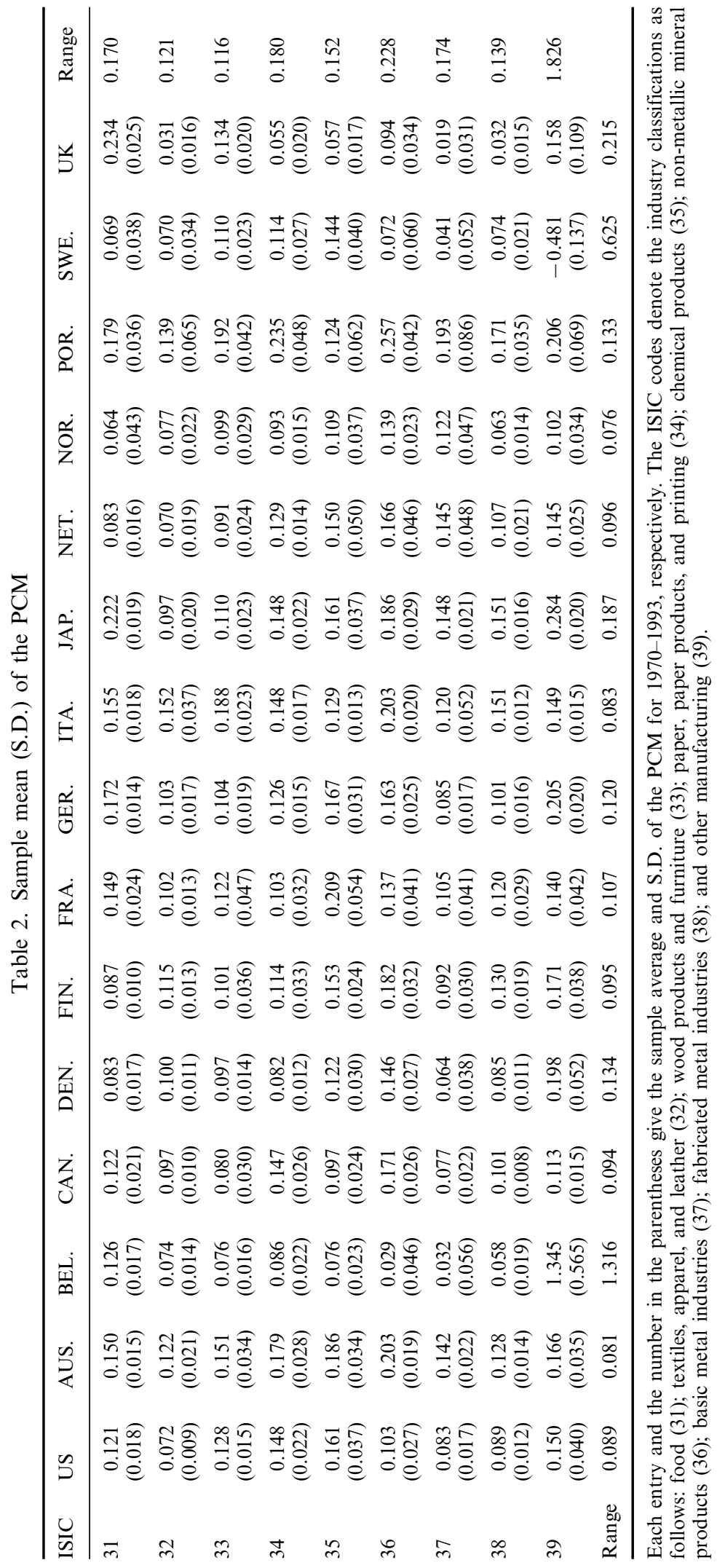


rate behavior. Similarly, in Dornbusch (1987) the monopolistic firm's pricing power is determined to be a function of the demand elasticity, which in turn depends crucially on the substitutability among varieties within an industry.

We utilize the intra-industry trade index (Grubel and Lloyd, 1975) as our second measure of market structure to reflect the market power due to product differentiation. The IIT index of sector $i$ in country $j$ in period $t$ is defined as

$$
\operatorname{IIT}_{i, t}^{j}=1-\frac{\left|E X_{i, t}^{j}-I M_{i, t}^{j}\right|}{\left(E X_{i, t}^{j}+I M_{i, t}^{j}\right)}
$$

where $E X_{i, t}^{j}$ and $I M_{i, t}^{j}$ represent sectoral exports and imports, respectively. A large value of the IIT index is interpreted as a high level of market power due to product differentiation. Table 3 presents the sample means and standard deviations of the IIT indexes. Not surprisingly, we observe fairly large IIT index values, particularly for the European countries. For many countries, the IIT index varies substantially across sectors, indicating heterogeneity in the market structure across the manufacturing sectors. Finland has the largest variation in the mean IIT indexes (the mean is 0.781) and Belgium and France have the lowest (the mean is 0.281 ). The industry IIT index also exhibits a wide variation across countries. The range of mean IIT index is widest for the paper, paper products and printing group, which has a range of 0.817 . The narrowest range is 0.430 computed for the chemical products industry. Compared with the mean PCMs in Table 2, the mean IIT indexes show a small degree of variability.

Since the PCM and IIT represent two different ways to characterize the market structure of an industry, they are likely to capture different aspects of market imperfection. In fact, the numbers in Tables 2 and 3 bear little resemblance. The sample correlation between the PCM and IIT index is pretty low at 0.06 , confirming that these two measures manifest different traits of market imperfection in these industries. The use of both PCM and IIT index, thus, offers us a better chance to reveal the effects of market structure on real exchange rate persistence.

\section{THE PERSISTENCE OF SECTORAL PPP DEVIATIONS}

With the empirical measures constructed in the preceding section, we analyze the relationship between market structure and sectoral real exchange rate persistence. The first regression specification is

$$
\mathrm{MRC}_{i}^{j}=\beta_{0}+\delta \mathrm{PCM}_{i}^{j}+\beta_{1} \mathrm{OPEN}_{i}^{j}+\beta_{2} \mathrm{INF}_{i}^{j}+\beta_{3} \mathrm{GOV}^{j}+\beta_{4} \mathrm{SVAR}^{j}+\beta_{5} \mathrm{DIST}^{j}+\eta_{i}^{j}
$$

where $\mathrm{MRC}_{i}^{j}$ is the mean reversion coefficient defined in Section 3.2, $\mathrm{PCM}_{i}^{j}$ is the index of $\mathrm{PCM}$ defined as the sum of the sector $i$ average PCM of the US and that of country $j$, and $\eta_{i}^{j}$ is the disturbance term. The second through the sixth regressors are included as control variables, and are defined and discussed below.

The fundamental idea of long-run PPP is that goods arbitrage ensures the parity condition across a range of individual goods over a certain time horizon. ${ }^{13}$ Accordingly, trade activity affects the PPP adjustment rate. In Faruqee (1995) and Bergin and Feenstra (1999) an increase in openness encourages price adjustment by firms to offset exchange rate changes, and thus, reduces the real exchange rate persistence. To control for the effect of openness, we include the variable $\mathrm{OPEN}_{i}^{j}$, which is defined as the sum of the sample average ratios of the imports plus exports to the total production in sector $i$ of the US and of country $j$.

The speed of parity reversion depends crucially on how quickly goods prices are adjusted. Under nominal rigidities a higher inflation rate leads to a more rapid price adjustment (Ball and Mankiw, 1994). Consequently, empirical evidence indicates that PPP holds well for high inflation countries (Frenkel, 1978; McNown and Wallace, 1989). Further, in their cross-country analysis Cheung and Lai (2000a) find that a higher level of inflation is associated with a lower level of real exchange rate persistence. These studies suggest that differences in sector-specific inflation may partly explain differences in sectoral real exchange rate persistence. Accordingly, Equation (9) includes $\mathrm{INF}_{i}^{j}$, which is defined as the sum of the average sectoral inflation rates of industry $i$ of the US and of country $j .{ }^{14}$ 


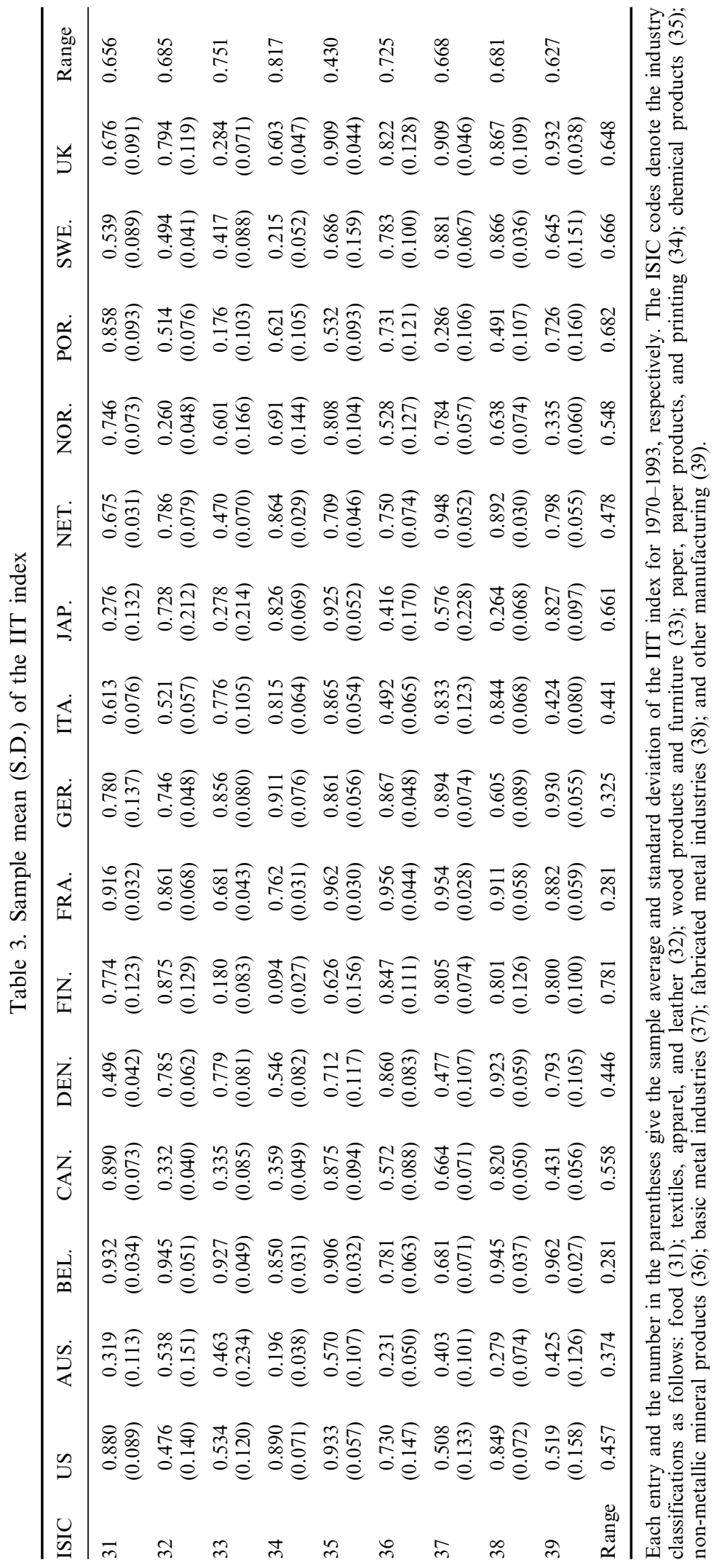


Some structural models of PPP deviations consider government spending as an important demand-side factor that creates a home goods bias (Froot and Rogoff, 1991; Rogoff, 1992). Bergin and Feenstra (1999) suggest that a stronger home goods bias leads to more persistent real exchange rate behavior. Empirically, Cheung and Lai (2000a) show that government spending is positively correlated with real exchange rate persistence. We therefore include the variable $\mathrm{GOV}^{j}$ which denotes the average of the ratios of government consumption to gross domestic product (GDP) of country $j$, to control for the country-specific demand-side effect.

$\mathrm{SVAR}^{j}$ in Equation (9) represents the exchange rate variability. It is the standard deviation of first log differences of the nominal exchange rate between the US and $j$. The variable is interpreted as a proxy for exchange rate uncertainty price-setters face. In his dynamic partial equilibrium model of a price-setting firm with menu costs, Delgado (1991) shows that variability of the nominal exchange rate raises the level of uncertainty, and hence, intensifies price stickiness. In other words, firms become less willing to change their prices since the exchange rate may move back after the price change and another price change in the opposite direction may become necessary.

A popular view of PPP/LOP deviations is that transportation costs create a wedge between prices in two countries (Dumas, 1992; Wei and Parsley, 1995). It follows that a greater geographical distance can lead to larger PPP/LOP deviations if transportation costs are proportional to distances (Wei and Parsley, 1995). In a recent study Campa and Wolf (1997) find that a greater geographical distance results also in slower PPP reversion. Thus, we add the variable $\mathrm{DIST}^{j}$, which is the geographical distance in logarithm between the US and country $j$ to capture the transportation cost effect. ${ }^{15}$

Using the $I(0)$ sectoral real exchange rate sample, a truncated regression specification is employed to estimate Equation (9). ${ }^{16}$ The sample is restricted to the $I(0)$ series due to the following reason. We anticipate a significant relationship between real exchange rate persistence and market structure when real exchange rates are mean reverting. At the unit root persistence threshold level, however, the relationship is not well defined and likely discontinuous. In fact, $\mathrm{MRC}_{i}^{j}$ is no longer a sensible measure of the persistence if sectoral real exchange rates are $I(1)$ series. ${ }^{17}$ Thus, to avoid inconsistent estimates, we only consider the mean reverting sectoral real exchange rates and estimate the truncated model specification using the maximum likelihood (ML) procedure.

The ML estimation results are summarized in the second column of Table 4. For comparison purposes, the results of the ordinary least squares (OLS) estimations are also reported in the third column. Most notably, the PCM term has a statistically significant positive effect on real exchange rate persistence-a result that is consistent with our hypothesis. That is, sectors with a larger PCM, interpreted as a greater degree of imperfectly competitive market structure, are associated with a slower rate of sectoral PPP reversion. The OLS estimation yields an even larger positive PCM effect. The estimation result suggests that market structure is indeed vital to the determination of real exchange rate persistence.

Also consistent with the prior, the effect of inflation is negative and significant, suggesting that industries with higher inflation rates experience faster sectoral real exchange rate parity reversion. While previous studies (Frenkel, 1978; McNown and Wallace, 1989; Cheung and Lai, 2000a) find that differences in national inflation rates lead to differences in real exchange rate persistence, the current study uncovers the similar phenomenon at the industry level, after controlling for the market structure effect. The implication is that sector-specific shocks, in addition to macroeconomic shocks, can be imperative to real exchange rate persistence.

The effect of trade openness appears puzzling. This variable has a significant positive coefficient indicating that the more open an industry is to international trade, the more persistent is its sectoral real exchange rate. ${ }^{18}$ The result is counter-intuitive and seems to contradict the goods arbitrage view of PPP reversion. The unexpected result, however, may be driven by the inverse relationship between openness and inflation (Romer, 1993). ${ }^{19}$ Among the explanatory variables, $\mathrm{OPEN}_{i}^{j}$ has the strongest correlation (in absolute value) with $\mathrm{INF}_{i}^{j}$. The sample correlation between these two variables is -0.24 . That is, a greater degree of openness is associated with a lower level of inflation, which implies a more persistent real exchange rate. Our estimation results, thus, suggest that the trade openness effect is dominated by the inflation effect. In fact, when $\mathrm{OPEN}_{i}^{j}$ is omitted from Equation (9), the significance of the inflation variable increases from the $10 \%$ level to the $1 \%$ level. ${ }^{20}$ 
Table 4. Effects of PCM and IIT on real exchange rate persistence

\begin{tabular}{|c|c|c|c|c|c|c|}
\hline & \multicolumn{2}{|c|}{ Price-cost margin } & \multicolumn{2}{|l|}{ IIT } & \multicolumn{2}{|c|}{ PCM and IIT } \\
\hline & ML & OLS & ML & OLS & ML & OLS \\
\hline $\mathrm{PCM}_{i}^{j}$ & $\begin{array}{l}0.5579^{* *} \\
(0.2393)\end{array}$ & $\begin{array}{l}0.7397 * * \\
(0.3196)\end{array}$ & & & $\begin{array}{l}0.4468^{*} \\
(0.2491)\end{array}$ & $\begin{array}{l}0.6367 * \\
(0.3237)\end{array}$ \\
\hline $\operatorname{IIT}_{i}^{j}$ & & & $\begin{array}{l}0.1367^{* * * *} \\
(0.0433)\end{array}$ & $\begin{array}{l}0.1373^{*} \\
(0.0716)\end{array}$ & $\begin{array}{l}0.1157^{* *} \\
(0.0466)\end{array}$ & $\begin{array}{r}0.1074 \\
(0.0716)\end{array}$ \\
\hline $\begin{array}{l}\text { Trade openness } \\
\left(\mathrm{OPEN}_{i}^{j}\right)\end{array}$ & $\begin{array}{l}0.0700^{* * *} \\
(0.0195)\end{array}$ & $\begin{array}{l}0.0967 * * * \\
(0.0357)\end{array}$ & $\begin{array}{l}0.0720 * * * \\
(0.0197)\end{array}$ & $\begin{array}{l}0.0897 * * \\
(0.0357)\end{array}$ & $\begin{array}{l}0.0806^{* * *} \\
(0.0200)\end{array}$ & $\begin{array}{l}0.1045^{* * *} \\
(0.0357)\end{array}$ \\
\hline $\begin{array}{l}\text { Inflation } \\
\left(\mathrm{INF}_{i}^{j}\right)\end{array}$ & $\begin{array}{l}-1.0778 * * \\
(0.4566)\end{array}$ & $\begin{array}{l}-1.2310^{* *} \\
(0.5504)\end{array}$ & $\begin{array}{r}-0.4112 \\
(0.5162)\end{array}$ & $\begin{array}{r}-0.5900 \\
(0.5772)\end{array}$ & $\begin{array}{r}-0.6908 \\
(0.5023)\end{array}$ & $\begin{array}{r}-0.9053 \\
(0.5865)\end{array}$ \\
\hline $\begin{array}{l}\text { Government spending } \\
\left(\mathrm{GOV}^{j}\right)\end{array}$ & $\begin{array}{l}0.7884^{* *} \\
(0.3322)\end{array}$ & $\begin{array}{l}1.2704^{* *} \\
(0.4958)\end{array}$ & $\begin{array}{l}0.6507 * * \\
(0.3234)\end{array}$ & $\begin{array}{l}0.9712 * * \\
(0.4863)\end{array}$ & $\begin{array}{l}0.7937 * * \\
(0.3304)\end{array}$ & $\begin{array}{l}1.2207 * * \\
(0.4919)\end{array}$ \\
\hline $\begin{array}{l}\text { Exch. rate volatility } \\
\left(\mathrm{SVAR}^{j}\right)\end{array}$ & $\begin{array}{l}1.6380^{* *} \\
(0.6573)\end{array}$ & $\begin{array}{l}1.6934^{*} \\
(0.9920)\end{array}$ & $\begin{array}{r}0.2612 \\
(0.7376)\end{array}$ & $\begin{array}{c}0.1996 \\
(1.1274)\end{array}$ & $\begin{array}{r}0.6172 \\
(0.7232)\end{array}$ & $\begin{array}{c}0.8106 \\
(1.1448)\end{array}$ \\
\hline $\begin{array}{l}\text { Geographical distance } \\
\left(\text { DIST }^{j}\right)\end{array}$ & $\begin{array}{r}-0.0157 \\
(0.0244)\end{array}$ & $\begin{array}{c}0.0128 \\
(0.0376)\end{array}$ & $\begin{array}{c}0.0193 \\
(0.0255)\end{array}$ & $\begin{array}{c}0.0600 \\
(0.0411)\end{array}$ & $\begin{array}{c}0.0095 \\
(0.0254)\end{array}$ & $\begin{array}{c}0.0399 \\
(0.0414)\end{array}$ \\
\hline Constant & $\begin{array}{c}0.3468 \\
(0.2136)\end{array}$ & $\begin{array}{r}-0.0806 \\
(0.3177)\end{array}$ & $\begin{array}{c}0.0868 \\
(0.2459)\end{array}$ & $\begin{array}{c}-0.3501 \\
(0.3798)\end{array}$ & $\begin{array}{c}0.0527 \\
(0.2429)\end{array}$ & $\begin{array}{r}-0.3771 \\
(0.3714)\end{array}$ \\
\hline
\end{tabular}

The PCM results, the IIT results, and the PCM and IIT results are based on Equations (9)-(11) in the text, respectively. The entries under the heading 'ML' present the maximum likelihood estimation results of the truncated regression. The entries under the heading 'OLS' present the results obtained by ordinary least squares.

$* * *, * *$, and $*$ indicate $1 \%, 5 \%$, and $10 \%$ statistical significance, respectively. The S.E. are provided in the parentheses.

The country-specific effect, government spending, is found to be statistically significant and has the expected sign. An increased share of government spending to GDP leads to a slower parity reversion. As the estimation allowed for the effects of market structure and other macro variables, our result regarding the effects of government spending on real exchange rate persistence is stronger than the one in Cheung and Lai (2000a), which is based on bivariate correlation analysis. Further the result is also complementary to those in Froot and Rogoff (1991) and Gagnon and Rose (1995), who find significant effects of government spending on real exchange rate movements in developed countries. Thus, the effects of government spending, which is typically interpreted as a demand-side factor, on real exchange rate variability and persistence are of both theoretical and empirical relevance.

Previous studies (Mussa, 1986; Grilli and Kaminsky, 1991) indicate the possible interaction between nominal and real exchange rate variabilities. Results in Table 5 show that exchange rate volatility can affect different aspects of real exchange rate dynamics. In addition to variability, exchange rate volatility also influences the persistence of real exchange rates. The result is supportive of the assertion that exchange rate variability intensifies price stickiness and real exchange rate persistence.

The effect of geographical distance is not significant and has a negative sign. The result is in contrast with that of Campa and Wolf (1997) who find that a greater distance is associated with a slower PPP reversion among G7 countries. To investigate the difference, we estimate a bivariate specification-regressing $\mathrm{MRC}_{i}^{j}$ on $\mathrm{DIST}^{j}$. When $\mathrm{DIST}^{j}$ is the only explanatory variable, it has a significantly positive sign - a result that is consistent with Campa and Wolf (1997). Thus, the insignificance of $\mathrm{DIST}^{j}$ in our regression framework suggests that the empirically relevant information in the distance variable is captured and dominated by other variables in the equation. In comparing the correlation between the explanatory variables, we found that DIST ${ }^{j}$ is highly correlated with $\mathrm{SVAR}^{j}$ and these two variables have a sample correlation coefficient of 0.60 . An interesting future research topic is to investigate why the distance effect can be subsumed under the exchange rate volatility. Our result, 
nonetheless, suggests that the reported distance effect may not be robust to the presence of other macro variables.

To examine the effect of IIT, we estimate

$$
\mathrm{MRC}_{i}^{j}=\beta_{0}+\lambda \mathrm{IIT}_{i}^{j}+\beta_{1} \mathrm{OPEN}_{i}^{j}+\beta_{2} \mathrm{INF}_{i}^{j}+\beta_{3} \mathrm{GOV}^{j}+\beta_{4} \mathrm{SVAR}^{j}+\beta_{5} \mathrm{DIST}^{j}+\eta_{i}^{j}
$$

where $\operatorname{IIT}_{i}^{j}$ is the sum of the sector $i$ average IIT index of the US and that of country $j$, and the other variables are as defined earlier. The fourth and fifth columns of Table 4 summarize the results. Consistent with the prediction, IIT has a highly significant positive effect on real exchange rate persistence. In other words, sectors with substantial IIT activity, interpreted as an indication of imperfect competition due to product differentiation, tend to have more persistent sectoral PPP deviations. Although the effects of trade openness and government spending are essentially the same, replacing PCM with IIT leads to insignificant coefficients for inflation and exchange rate variability. The OLS estimation result is qualitatively similar to the ML one although the statistical significance level of the IIT effect declines to the $10 \%$ level.

By construction, the variables PCM and IIT capture different aspects of market imperfection. In order to examine whether PCM and IIT are representing different aspects of the market structure effect, we include both terms in the regression model simultaneously, and estimate Equation (11)

$$
\mathrm{MRC}_{i}^{j}=\beta_{0}+\delta \mathrm{PCM}_{i}^{j}+\lambda \mathrm{IIT}_{i}^{j}+\beta_{1} \mathrm{OPEN}_{i}^{j}+\beta_{2} \mathrm{INF}_{i}^{j}+\beta_{3} \mathrm{GOV}^{j}+\beta_{4} \mathrm{SVAR}^{j}+\beta_{5} \mathrm{DIST}^{j}+\eta_{i}^{j}
$$

The results are reported in the last two columns of Table 4. The effects of PCM and IIT remain positive and significant at the $10 \%$ and $5 \%$ levels, respectively. This suggests that PCM and IIT are indeed capturing different aspects of the market structure effect and they both are positively associated with sectoral real exchange rate persistence. The effects of the other control variables are similar to those in the preceding results. Again, we confirm that the negative effect of sectoral inflation rates becomes highly significant once the openness variable is omitted from Equation (11). Overall, the estimation results of Equations (9)-(11) suggest that market structure has a significant effect upon real exchange rate persistence. When the indicators of market imperfection, as measured by PCM and IIT index, increase, the corresponding sectoral real exchange rates become more persistent, and exhibit a slower reversion to sectoral PPP.

In order to see if the market structure variables as a group add to the explanatory power of distance, inflation, openness and government spending, we conducted a series of $\chi^{2}$ tests. The hypothesis that the coefficients of $\mathrm{PCM}_{i}^{j}$ and $\mathrm{IIT}_{i}^{j}$ are jointly insignificant is rejected at the $5 \%$ marginal significance level. The effects of market structure on the sectoral real exchange rate persistence seem quite pervasive.

\section{ADDITIONAL ANALYSES}

\subsection{The relative $P C M$}

In this section, we examine a few more additional specifications to evaluate the robustness of the market structure effect reported in the previous section. In Table 2, we notice that some countries have relatively high average PCMs across sectors while others have relatively low values across sectors. A comparison between Australia and Belgium, or Portugal and Norway, serves as a good example. To investigate if such country-specific effects have any implications for the results reported in the previous section, we rescale PCM of each sector by subtracting the PCM of total manufacturing of the corresponding country. Using these relative PCM (RPCM) measures, we re-estimate Equations (9) and (11) and report the results in Appendix A. The results based on RPCM are qualitatively similar to the previous ones. The effect of RPCM is positive and statistically significant, and estimates of other coefficients are stable. When both RPCM and IIT are included simultaneously, the effect of IIT dominates in terms of significance. The $\chi^{2}$ test results indicate that RPCM and IIT together add significantly to the explanatory power of the model. The hypothesis that the coefficients on $\mathrm{RPCM}_{i}^{j}$ and 
$\mathrm{IIT}_{i}^{j}$ are jointly zero is rejected at the $5 \%$ significance level. Overall, the finding of market structure effects on sectoral real exchange rate persistence is not sensitive to the modification of the PCM variable.

\subsection{The price markup over marginal cost}

The PCM measures the margin between price and average cost. Another measure of market power is the gap between price and marginal cost which is usually not directly observable from the data. Hall (1988) proposes a technique to estimate the industry price markup over marginal cost, and applies it to the US manufacturing industries. ${ }^{21}$ Using this technique, we estimate the sectoral price markup over marginal cost. ${ }^{22}$ The details of the estimation procedures are provided in Appendix B. We repeat the regression analysis in Section 4 using the price markup as an indicator of market structure and report the results in Table 6 in Appendix B.

The estimation results consistently yield the expected positive coefficient for the price markup variable, but the estimate is generally insignificant. The signs and significance of other variables are fairly stable. It is likely that the insignificance of the price markup variable is related to the fact that it is a generated regressor, and is estimated with considerable inaccuracy. ${ }^{23}$ Nonetheless, when all of the three measures of market structure are included jointly in the model, the price markup variable is significant at the $10 \%$ level, while PCM and the IIT index are significant at the 5\% and $1 \%$ levels, respectively. The result implies that price markup, PCM, and IIT are capturing different effects of market structure which complement, rather than substitute for, each other. Note that all three measures have the signs that are consistent with the priors. That is, they all suggest that market imperfection is related to persistence in sectoral real exchange rates. Overall, the effects of market structure variables remain fairly robust. ${ }^{24}$

\section{SUMMARY}

One intriguing issue is the marked persistence exhibited by real exchange rates in the post-Bretton period. While the slow speed of reversion to PPP is quite extensively documented, the determinants of the adjustment process have not been extensively studied. In particular, no previous studies have empirically investigated the effect of market imperfection, as measured by PCM and IIT, on real exchange rate persistence.

Using data on US dollar-based sectoral real exchange rates for 14 OECD countries, this study investigates the empirical relationship between market structure and real exchange rate persistence, taking into consideration the effects of macroeconomic variables commonly believed to affect PPP adjustment. Industry-level data are used to construct two measures of market structure: the PCM and IIT index. In general, the sample PCM and IIT index display considerable variations across countries and industries. Further the correlation between the two measures is smaller; indicating that they are capturing different aspects of market imperfection.

The econometric results reveal considerable evidence for the hypothesis that market imperfection is associated with high PPP persistence. In general, the two measures of market imperfection, PCM and IIT index, are significant across different specifications and have a positive impact on real exchange rate persistence. The robustness of the market structure effects stands in stark contrast with the results pertaining to the macroeconomic variables, which can yield coefficient estimates that vary across model specifications, and occasionally, have a sign different from that predicted by theory. Overall, our analysis uncovers some positive evidence of market structure effects on real exchange rate persistence.

Future study of the relationship between market structure effects should benefit from the availability of better quality data on price and cost structure at finer detail. Unfortunately, at the current moment, the relevant cross-country data even for the ISIC three-digit classifications are difficult to come by. An interesting future research project would entail the collection and construction of data that would allow for direct examination of these effects at the disaggregated industry level. 


\section{ACKNOWLEDGEMENTS}

We thank Mike Dooley, Dan Friedman, K. C. Fung, Linda Goldberg, Ken Kletzer, Manuel Pastor, Jr, Donald Wittman, and the participants of the Purchasing Power Parity session of the 1999 AEA Annual Meeting and the Economics Brown Bag Seminar at UCSC for their comments on earlier drafts. This research is supported by funds from the UC Pacific Rim Research Program.

\section{APPENDIX A}

\section{A.1. The relative $P C M$}

The relative PCM (RPCM) is defined as

$$
\operatorname{RPCM}_{i, t}^{j}=\mathrm{PCM}_{i, t}^{j}-\mathrm{PCM}_{m, t}^{j}
$$

where $\mathrm{PCM}_{i, t}^{j}$ is the $\mathrm{PCM}$ of sector $i$, and $\mathrm{PCM}_{m, t}^{j}$ is the PCM of the total manufacturing sector of country $j$ in period $t . \mathrm{PCM}_{m}^{j}$ is calculated from the data on the total manufacturing (ISIC 30). Let $\mathrm{RPCM}_{i}^{j}$ denote the sum of the average sector $i$ RPCMs of the US and that of country $j$. By replacing $\operatorname{PCM}_{i}^{j}$ in Equations (9) and (11) in the main text with $\operatorname{RPCM}_{i}^{j}$, we estimate:

$$
\mathrm{MRC}_{i}^{j}=\beta_{0}+\delta \mathrm{RPCM}_{i}^{j}+\beta_{1} \mathrm{OPEN}_{i}^{j}+\beta_{2} \mathrm{INF}_{i}^{j}+\beta_{3} \mathrm{GOV}^{j}+\beta_{4} \mathrm{SVAR}^{j}+\beta_{5} \mathrm{DIST}^{j}+\eta_{i}^{j}
$$

and

$$
\mathrm{MRC}_{i}^{j}=\beta_{0}+\delta \mathrm{RPCM}_{i}^{j}+\lambda \mathrm{IIT}_{i}^{j}+\beta_{1} \mathrm{OPEN}_{i}^{j}+\beta_{2} \mathrm{INF}_{i}^{j}+\beta_{3} \mathrm{GOV}^{j}+\beta_{4} \mathrm{SVAR}^{j}+\beta_{5} \mathrm{DIST}^{j}+\eta_{i}^{j}
$$

\begin{tabular}{|c|c|c|c|c|}
\hline & \multicolumn{2}{|l|}{ RPCM } & \multicolumn{2}{|c|}{ RPCM and IIT } \\
\hline & ML & OLS & ML & OLS \\
\hline $\mathrm{RPCM}_{i}^{j}$ & $\begin{array}{l}0.5128^{* *} \\
(0.2491)\end{array}$ & $\begin{array}{c}0.6691^{*} \\
(0.3509)\end{array}$ & $\begin{array}{r}0.4099 \\
(0.2555)\end{array}$ & $\begin{array}{r}0.5693 \\
(0.3516)\end{array}$ \\
\hline $\operatorname{IIT}_{i}^{j}$ & & & $\begin{array}{l}0.1220^{* * * *} \\
(0.0464)\end{array}$ & $\begin{array}{c}0.1171 \\
(0.0718)\end{array}$ \\
\hline Trade openness $\left(\mathrm{OPEN}_{i}^{j}\right)$ & $\begin{array}{l}0.0623^{* * *} \\
(0.0184)\end{array}$ & $\begin{array}{l}0.0864^{* *} \\
(0.0355)\end{array}$ & $\begin{array}{l}0.0752^{* * *} \\
(0.0194)\end{array}$ & $\begin{array}{l}0.0965^{* * *} \\
(0.0355)\end{array}$ \\
\hline Inflation $\left(\mathrm{INF}_{i}^{j}\right)$ & $\begin{array}{c}-0.9222^{* *} \\
(0.4545)\end{array}$ & $\begin{array}{c}-1.0278^{*} \\
(0.5459)\end{array}$ & $\begin{array}{r}-0.5477 \\
(0.4938)\end{array}$ & $\begin{array}{r}-0.7039 \\
(0.5740)\end{array}$ \\
\hline Government spending $\left(\mathrm{GOV}^{j}\right)$ & $\begin{array}{c}0.5420^{*} \\
(0.3265)\end{array}$ & $\begin{array}{c}0.9306^{*} \\
(0.4872)\end{array}$ & $\begin{array}{c}0.5989^{*} \\
(0.3265)\end{array}$ & $\begin{array}{c}0.9279^{*} \\
(0.4807)\end{array}$ \\
\hline Exch. rate variability $\left(\mathrm{SVAR}^{j}\right)$ & $\begin{array}{l}1.5482^{* *} \\
(0.6610)\end{array}$ & $\begin{array}{c}1.5082 \\
(0.9954)\end{array}$ & $\begin{array}{c}0.4915 \\
(0.7260)\end{array}$ & $\begin{array}{c}0.5752 \\
(1.1366)\end{array}$ \\
\hline Geographical distance $\left(\right.$ DIST $\left.^{j}\right)$ & $\begin{array}{r}-0.0085 \\
(0.0247)\end{array}$ & $\begin{array}{c}0.0235 \\
(0.03768)\end{array}$ & $\begin{array}{c}0.0166 \\
(0.0255)\end{array}$ & $\begin{array}{c}0.0514 \\
(0.0409)\end{array}$ \\
\hline Constant & $\begin{array}{l}0.4545^{* *} \\
(0.2052)\end{array}$ & $\begin{array}{r}0.0622 \\
(0.3166)\end{array}$ & $\begin{array}{r}0.1215 \\
(0.2416)\end{array}$ & $\begin{array}{r}-0.2823 \\
(0.3772)\end{array}$ \\
\hline
\end{tabular}

The estimation results are summarized in Table 5 .

Table 5. Effects of RPCM and IIT on sectoral real exchange rate persistence

The entries under the heading 'ML' present the maximum likelihood estimation results of the truncated regression. The entries under the heading 'OLS' present the results obtained by ordinary least squares. $* * *, * *, *$ indicate $1 \%, 5 \%, 10 \%$ statistical significance, respectively. S.E. are provided in parentheses. 


\section{APPENDIX B}

\section{B.1. The price markup over marginal cost by the method of Hall (1988)}

The Hall (1988) method estimates the price markup over marginal cost by

$$
\Delta y_{i, t}-\alpha_{i, t}^{L} \Delta l_{i, t}-\alpha_{i, t}^{M} \Delta m_{i, t}=(1-\rho) \theta_{i}+\rho \Delta y_{i, t}+(1-\rho) \Delta \alpha_{i, t}
$$

where

$$
\rho \equiv(P-M C) / P
$$

$y_{i, t} \equiv \ln \left(Y_{i, t} / K_{i, t}\right), l_{i, t} \equiv \ln \left(L_{i, t} / K_{i, t}\right), m_{i, t} \equiv \ln \left(M_{i, t} / K_{i, t}\right)$ and $a_{i, t} \equiv \ln A_{i, t}$, for which $Y_{i, t}, K_{i, t}, L_{i, t}, M_{i, t}$ and $A_{i, t}$ denote output, capital, labor, material input, and random productivity shock, respectively. $\theta_{i}$ represents the constant rate of Hicks-neutral technology progress. $\alpha_{i, t}^{L}$ and $\alpha_{i, t}^{M}$ denote the labor share and the material share of the output, respectively. $P$ is the price and $M C$ is the marginal cost. Under the assumption of constant returns to scale and perfect competition, the price is equal to the marginal cost, and hence, $\rho$ equals 0 . Under imperfect competition, however, the price exceeds the marginal cost, and therefore, $\rho$ takes a positive value.

To account for the endogeneity, we estimate (Equation (B1)) using two commonly adopted instruments: the growth rate of crude fuel prices (Hall, 1988) and the current and lagged growth rate of GDP (Domowitz et al., 1988). The sectoral data are taken from STAN Industrial Database and ISDB. The real gross capital stock is used as a measure for the capital. The labor is proxied by the number of total employees. The share of labor in the output is measured by the ratio of total compensation to the total production. The annual real GDP data is obtained from IFS. The monthly data on crude fuel price for the manufacturing industry is obtained from DRI Basic Economics, and the annual series is derived from period averages. Then, the sector-specific deflator is used to calculate the real sector-specific oil price. Due to the limited coverage of the capital stock data in ISDB, we are unable to estimate (Equation (B1)) for Australia, the Netherlands, and Portugal. In addition, there are seven other sectors for which markups are not estimated due to missing observations: wood products and furniture for Belgium, Italy, and Japan; non-metallic mineral products for Norway; other manufacturing for Belgium, France, and Norway.

The estimated values of $\rho$ in (Equation (B1)) are reported in Table 6. In 71 cases (including the US) the estimates of $\rho$ have a positive significant value at the 5\% level. For the cases where the estimated $\rho$ is not significantly different from zero, the price markup is assumed to be zero. With the estimated price markup, we examine the effect of market structure on the sectoral real exchange rate persistence using

$$
\mathrm{MRC}_{t}^{j}=\beta_{0}+\phi \mathrm{MKUP}_{t}^{j}+\beta_{1} \mathrm{OPEN}_{t}^{j}+\beta_{2} \mathrm{INF}_{t}^{j}+\beta_{3} \mathrm{GOV}^{j}+\beta_{4} \mathrm{SVAR}^{j}+\beta_{5} \mathrm{DIST}^{j}+\eta_{t}^{j}
$$

where MKUP $_{i}^{j}$ denotes the sum of the estimated sector $i$ price markup over marginal cost of the US and that of country $j$. In addition, we add the other measures of market structure, PCM and IIT index, one at a time to (Equation (B3)) and examine their effects. The results are summarized in Table 7.

\section{APPENDIX C. DATA APPENDIX}

\section{C.1. Sectoral data source}

OECD Structural Analysis (STAN) Industrial Database (December 1994), and OECD International Sectoral Database (ISDB) (version 95).

\section{C.2. Countries}

The USA, Australia, Belgium, Canada, Denmark, Finland, France, Germany, Italy, Japan, the Netherlands, Norway, Portugal, Sweden, UK. 


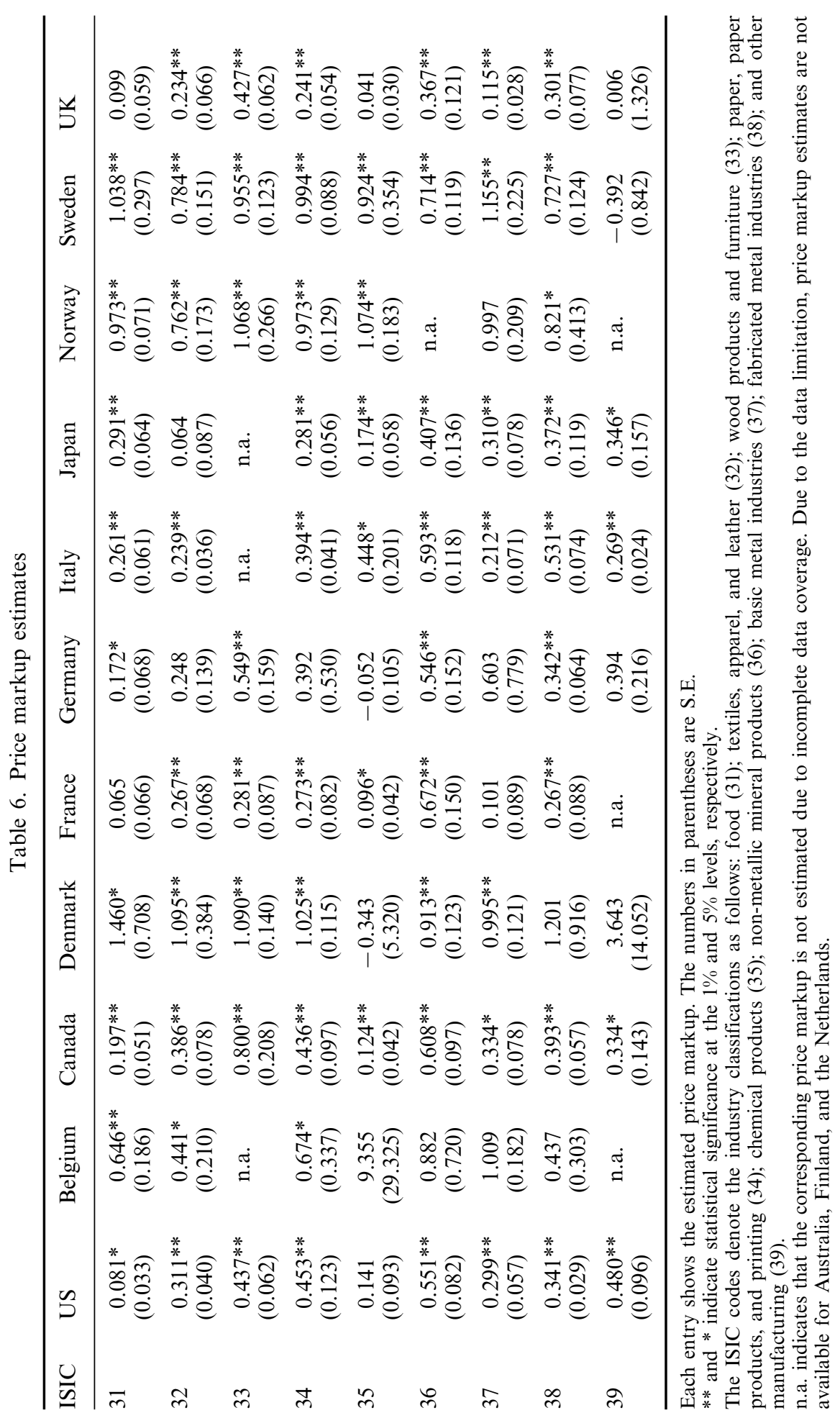




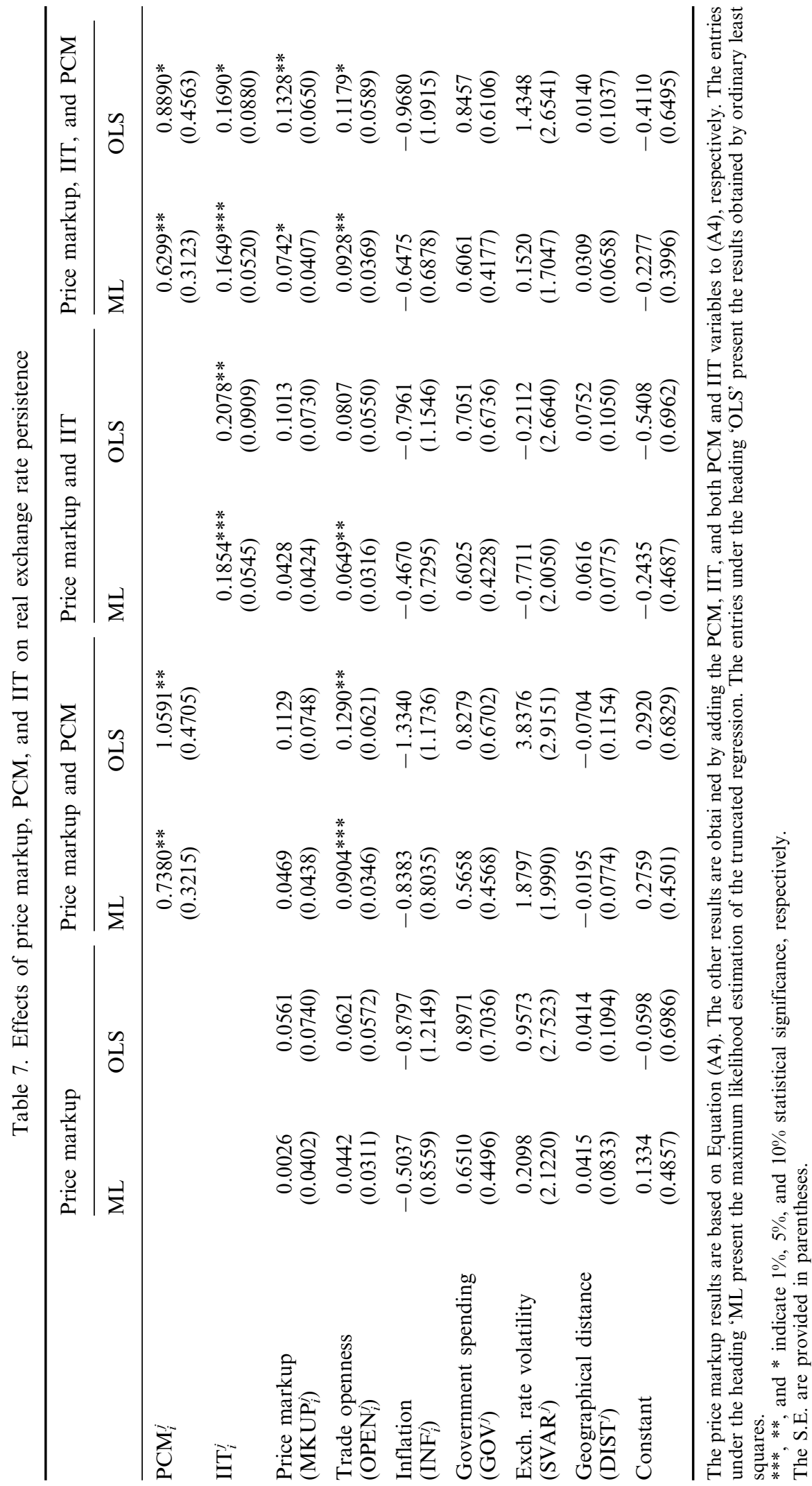




\section{C.3. Industries}

ISIC Classification $\begin{aligned} & \text { Products contained in the classification code } \\ & \text { description }\end{aligned}$

\begin{tabular}{|c|c|c|}
\hline 31 & $\begin{array}{l}\text { Food, beverages, and } \\
\text { tobacco }\end{array}$ & Food, beverages, and tobacco \\
\hline 32 & $\begin{array}{l}\text { Textiles, apparel, and } \\
\text { leather }\end{array}$ & Textiles, wearing apparel, leather and products, footwear \\
\hline 33 & $\begin{array}{l}\text { Wood products and } \\
\text { furniture }\end{array}$ & Wood products, furniture and fixtures \\
\hline 34 & $\begin{array}{l}\text { Paper, paper products, } \\
\text { and printing }\end{array}$ & Paper and products, printing and publishing \\
\hline 35 & Chemical products & $\begin{array}{l}\text { Industrial chemicals, other chemicals, drugs and medicines, other } \\
\text { chemical products, petroleum refineries, petroleum and coal } \\
\text { products, plastic products (not elsewhere classified) }\end{array}$ \\
\hline 36 & $\begin{array}{l}\text { Non-metallic mineral } \\
\text { products }\end{array}$ & $\begin{array}{l}\text { Pottery, china, etc., glass and products, non-metallic products (not } \\
\text { elsewhere classified) }\end{array}$ \\
\hline 37 & Basic metal industries & Iron and steel, non-ferrous metals \\
\hline 38 & $\begin{array}{l}\text { Fabricated metal } \\
\text { products }\end{array}$ & $\begin{array}{l}\text { Metal products, non-electrical machinery, office and computing } \\
\text { machinery, machinery and equipment (not elsewhere classified), } \\
\text { electrical machinery, radio, TV and communication equipment, } \\
\text { electrical apparatus (not elsewhere specified), transport equipment, } \\
\text { shipbuilding and repairing, radio equipment, motor vehicles, motor } \\
\text { cycles and bicycles, aircraft, transport equipment (not elsewhere } \\
\text { classified), professional goods }\end{array}$ \\
\hline 39 & Other manufacturing & Other manufacturing (not elsewhere classified) \\
\hline
\end{tabular}

\section{NOTES}

1. Examples include Abuaf and Jorion (1990), Diebold et al., (1991), Glen (1992), Culver and Papell (1995), and Lothian and Taylor (1996).

2. See Taylor and Sarno (1998) for the limitation of panel data unit root tests. Non-panel studies using the post-Bretton Woods data are typically less favorable to long-run PPP (Meese and Rogoff, 1988; Mark, 1990). An exception is Cheung and Lai (1998). Also, see Engel (2000) for an alternative view.

3. Goldberg and Knetter (1997) provide a comprehensive literature survey of PTM and the closely related subject of exchange rate pass-through.

4. As Dornbusch (1987) points out, if demand curves have constant price elasticities in both foreign and domestic markets, a monopolistically competitive firm will follow a constant markup pricing rule, and the relative price of its product will remain constant as the exchange rate fluctuates even if markets are effectively segmented. On the other hand, any demand curve less convex than a constant elasticity curve will result in PTM. See also Marston (1990) for a more detailed discussion and a comparative static analysis.

5. The model assumes two countries resided by representative consumer/producer agents engaging in either inter-sectoral or intra-sectoral trade in the presence of menu costs and staggered price adjustment. With inter-sectoral trade, countries specialize and trade at the industry level, while they trade at the variety level under intra-industry trade.

6. In Faruqee (1995), PTM occurs despite the constant elasticity demand functions since the cost is assumed to be separable for domestic and export markets.

7. See Appendix $\mathrm{C}$ for a more detailed description of the classifications.

8. Due to incomplete data coverage in the STAN database, we omitted Austria, Korea, Mexico, New Zealand and Spain from the analysis.

9. The 'number engaged' refers to the number of employees as well as self-employed, owner proprietors, and unpaid family workers of a given industry.

10. AR(1) coefficients are often used as a proxy to capture the persistence of a time series. For instance, Campa and Wolf (1997) utilizes the AR(1) coefficient from a Dickey-Fuller test as their measure of the speed of parity reversion. 
11. As pointed out by Cheung and Lai (2000b), there may be uncertainty about persistence measured by point estimates since they can be accompanied by substantial standard errors. Such uncertainty could result in empirical results that understate, but not overstate, the significance of market structure effect.

12. In terms of half-lives, the range corresponds to 2.8 months -3.3 years, with the mean equal to 1.48 years.

13. Campa and Wolf (1997), however, report that large real exchange rate deviations and large trade deviations are not systematically related.

14. We also considered country-specific inflation rates rather than sector-specific rates. For all of the specifications we estimated, the choice between the two different inflation rates does not alter the results significantly. The results based on the country-specific inflation rates are available upon request.

15. We follow the common practice (Wei and Parsley, 1995; Campa and Wolf, 1997) of using the distances between national capitals as a proxy for the distances between countries.

16. For truncated regression models, see Maddala (1983) and Dhrymes (1984). The Eicker-White method is used to calculate the asymptotic covariance matrix of the parameter estimates and standard errors. The method is a combination of analytical second derivatives and Berndt-Hall-Hall-Hausman method, and is robust to the distributional assumption. See White (1982) for details.

17. Under the unit root hypothesis, the estimated AR(1) coefficient is downward biased.

18. Campa and Wolf (1997) obtain a similar result for G7 countries using bilateral trade shares to measure openness.

19. See Romer (1993) for theoretical reasons for the inverse relationship between openness and inflation. In our sample, a significant inverse relationship exists also between openness and national inflation.

20. The estimation result is available upon request.

21. The method is adopted also by Domowitz et al. (1988), Hall (1990), and Harrison (1994). See Bresnahan (1989) and Feenstra (1995) for a summary and discussion of the method of Hall (1988).

22. Due to the limited coverage of the capital stock data in ISDB, the price mark-up cannot be estimated for some sectors. Thus, the subsequent regression analysis is based on a smaller sample than in the preceding sections. See Appendix A for the details.

23. A comparison of Table 2 in the main text and Table 6 in Appendix B reveals that the estimated mark-ups are much more variable than the calculated margins. Another possible reason for the insignificant results is the assumption required by the Hall method that the price mark-up is constant over time. It is via varying price markup that imperfectly competitive firms can price discriminate across markets in common currency terms as exchange rates fluctuate.

24. The estimations in this section are repeated by replacing the estimated price mark-ups with the estimated relative price mark-ups. These relative mark-ups are obtained by subtracting the estimated mark-up for the entire manufacturing industry from the individual estimated mark-ups. The results are qualitatively similar to those based on the estimated price mark-ups, and are available upon request.

\section{REFERENCES}

Abuaf N, Jorion P. 1990. Purchasing power parity in the long run. Journal of Finance 45: 157-174.

Ball L, Mankiw NG. 1994. Asymmetric price adjustment and economic fluctuations. Economic Journal 104: 247-261.

Bergin PR, Feenstra RC. 1999. Pricing to market, staggered contracts, and real exchange rate persistence. W7026 NBER Working Paper.

Bresnahan T. 1989. Empirical studies of industries with market power. In Handbook of Industrial Organization, Schmalensee R, Willig R (eds). North-Holland: Amsterdam; 1011-1057.

Campa JM, Goldberg LS. 1995. Investment in manufacturing, exchange rates and external exposure. Journal of International Economics 38: $297-320$.

Campa JM, Wolf HC. 1997. Is real exchange rate mean reversion caused by arbitrage? NBER Working Paper 6162.

Cheung Y-W, Lai KS. 1995. Lag order and critical values of a modified Dickey-Fuller test. Oxford Bulletin of Economics and Statistics 57: 411-419.

Cheung Y-W, Lai KS. 1998. Parity reversion in real exchange rates during the post-Bretton Woods period. Journal of International Money and Finance 17: 597-614.

Cheung Y-W, Lai KS. 2000a. On cross-country differences in the persistence of real exchange rates. Journal of International Economics 50: $375-397$.

Cheung Y-W, Lai KS. 2000b. On the purchasing power parity puzzle. Journal of International Economics 52: 321-330.

Culver SE, Papell DH. 1995. Real exchange rates under the Gold Standard: can they be explained by the trend break model? Journal of International Money and Finance 14: 539-548.

Delgado FA. 1991. Hysteresis, menu costs, and pricing with random exchange rates. Journal of Monetary Economics 28: 461-484.

Dhrymes P. 1984. Limited dependent variables. In Handbook of Econometrics, Griliches Z, Intriligator M (eds). North-Holland: Amsterdam; 1567-1631.

Diebold FX, Husted S, Rush M. 1991. Real exchange rates under the gold standard. Journal of Political Economy 99: 1252-1271.

Dixit A, Stiglitz JE. 1977. Monopolistic competition and optimum product diversity. American Economic Review 67: $297-308$.

Domowitz I, Hubbard RG, Peterson BC. 1988. Market structure and cyclical fluctuations in US manufacturing. Review of Economics and Statistics 70: 55-66.

Dornbusch R. 1987. Exchange rates and prices. American Economic Review 77: 93-106.

Dumas B. 1992. Dynamic equilibrium and the real exchange rate in a spatially separated world. Review of Financial Studies 5: $153-180$.

Elliott G, Rothenberg TJ, Stock JH. 1996. Efficient tests for an autoregressive unit root. Econometrica 64: 813-836.

Engel C. 2000. Long-run PPP may not hold after all. Journal of International Economics 51: 243-273.

Engel C, Hendrickson MK, Rogers JH. 1997. Intranational, intracontinental, and intraplanetary PPP. Journal of the Japanese and International Economies 11: 480-501. 
Faruqee H. 1995. Pricing to market and the real exchange rate. IMF Staff Papers 42: 855-881.

Feenstra RC. 1995. Estimating the effects of trade policy. In Handbook of International Economics, Grossman G, Rogoff K (eds). North-Holland: Amsterdam.

Feenstra RC, Kendall JD. 1997. Pass-through of exchange rates and purchasing power parity. Journal of International Economics 43: $237-261$.

Frenkel JA. 1978. Purchasing power parity: doctrinal perspective and evidence from the 1920s. Journal of International Economics 8: $169-191$.

Frankel JA, Rose AK. 1996. A panel project on purchasing power parity: mean reversion within and between countries. Journal of International Economics 40: 209-224.

Froot KA, Rogoff K. 1991. The EMS, the EMU, and the transition to a common currency. In 1991 NBER Macroeconomic Annual, Blanchard O, Fischer S (eds). MIT Press: Cambridge.

Gagnon JE, Rose AK. 1995. Panel evidence on the determinants of the real exchange rate manuscript. Federal Reserve Board and University of California, Berkeley.

Ghosh AR, Wolf HC. 1994. Pricing in international markets: lessons from The Economist. NBER Working Paper 4806.

Glen J. 1992. Real exchange rates in the short, medium, and long run. Journal of International Economics 33: 147-166.

Goldberg PK, Knetter MM. 1997. Goods prices and exchange rates: what have we learned? Journal of Economic Literature 35: $1243-1272$.

Grilli V, Kaminsky G. 1991. Nominal exchange rate regimes and the real exchange rate: evidence from the United States and Great Britain, 1885-1986. Journal of Monetary Economics 27: 191-212.

Grossman GM, Helpman E. 1991. Innovation and Growth in the Global Economy. MIT Press: Cambridge.

Grubel HG, Lloyd PJ. 1975. Intra-industry Trade: The Theory and Measurement of International Trade in Differentiated Products. Wiley: New York.

Hall RE. 1988. The relation between price and marginal cost in US industry. Journal of Political Economy 96: 921-947.

Hall RE. 1990. Invariance properties of Solow's productivity residuals. In Growth/Productivity/Unemployment, Diamond P (ed.). MIT Press: Cambridge; $71-112$.

Harrison A. 1994. Productivity, imperfect competition and trade reform. Journal of International Economics 36: 53-74.

Haskel J, Wolf HC. 1999. Why does the 'Law of one price' fail? A Case Study CEPR Discussion Paper 2187.

Helpman E. 1981. International trade in the presence of product differentiation, economies of scale, and imperfect competition: a Chamberlin-Heckscher-Ohlin approach. Journal of International Economics 11: 305-340.

Knetter MM. 1993. International comparisons of pricing-to-market behavior. American Economic Review 83: 473-486.

Krugman P. 1987. Pricing to market when the exchange rate changes. In Real-Financial Linkages among Open Economies, Arndt SW, Richardson JD (eds). MIT Press: Cambridge; 49-70.

Krugman P. 1995. Increasing returns, imperfect competition and the positive theory of international trade. In Handbook of International Economics, Grossman G, Rogoff K (eds). North-Holland: Amsterdam; 1243-1277.

Lothian JR, Taylor MP. 1996. Real exchange rate behavior: The recent float from the perspective of the past two centuries. Journal of Political Economy 104: 488-509.

Maddala G. 1983. Limited Dependent and Qualitative Variables in Econometrics. Cambridge University Press: New York.

Mark N. 1990. Real exchange rates in the long run: an empirical investigation. Journal of International Economics 28: 115-136.

Marston R. 1990. Pricing to market in Japanese manufacturing. Journal of International Economics 29: 217-236.

McNown R, Wallace MS. 1989. National price levels, purchasing power parity, and cointegration: A test of four high-inflation economies. Journal of International Money and Finance 8: 533-545.

Meese R, Rogoff K. 1988. Was it real? The exchange rate interest differential relation over the modern floating exchange rate period. Journal of Finance 43: 933-948.

Mussa M. 1986. Nominal exchange rate regimes and the behavior of real exchange rates: Evidence and implications. Carnegie Rochester Conference Series on Public Policy 25: 117-214.

Oh KY. 1996. Purchasing power parity and unit root tests using panel data. Journal of International Money and Finance 15: 405-418.

Pantula SG, Gonzalez-Farias G, Fuller WA. 1994. A comparison of unit-root test criteria. Journal of Business and Economics Statistics 12: 449-459.

Papell DH. 1997. Searching for stationarity: purchasing power parity under the recent float. Journal of International Economics 43: $313-332$.

Rogoff K. 1992. Traded goods consumption smoothing and the random walk behavior of the real exchange rate. Bank of Japan Monetary and Economic Studies 10: 1-29.

Rogoff K. 1996. The purchasing power parity puzzle. Journal of Economic Literature 34: 647-668.

Romer D. 1993. Openness and inflation: theory and evidence. Ouarterly Journal of Economics 108: 869-903.

Stock JH. 1994. Unit roots, structural breaks, and trends. In Handbook of Econometrics, Engle RF, McFadden DI (eds). North-Holland: Amsterdam; 2739-2841.

Taylor MP, Sarno L. 1998. The behavior of real exchange rates during the post-Bretton Woods period. Journal of International Economics 46: $281-312$.

Wei S-J, Parsley D. 1995. Purchasing power dis-parity during the floating rate period: Exchange rate volatility, trade barriers, and other culprits. NBER Working Paper 5032.

White H. 1982. Maximum likelihood estimation of misspecified models. Econometrica 50: 1-25.

Wu Y. 1996. Are real exchange rates nonstationary? Evidence from a panel-data test. Journal of Money, Credit and Banking 28: $54-63$. 